\title{
THE USE OF EVALUATIVE LANGUAGE IN EFL TEACHERS' REFLECTIVE JOURNAL WRITING: A CORPUS BASED STUDY
}

\section{EL USO DEL LENGUAJE EVALUATIVO EN LOS DIARIOS REFLEXIVOS DE LOS PROFESORES DE INGLÉS EN FORMACIÓN: UN ESTUDIO DE CORPUS}

\author{
Isabel Alonso-Belmonte \\ Universidad Autónoma de Madrid, Spain \\ isabel.alonso@uam.es
}

\begin{abstract}
This article presents a computer-assisted discourse analysis of the main topics and evaluative parameters used by student teachers of English as a Foreign Language (EFL) in their reflective journals. By applying Bednarek's parameter-based approach to the study of evaluation, 329 reflective journals (aprox. 90,000 words) were analyzed by using the UAM Corpus Tool. The correlation of three sources of data - topic analysis, evaluative parameters and keywords - allowed to uncover the most typical evaluative language choices made by EFL student teachers in their reflective journals and their overall evaluation of their training process during their practicum studies. Results show that most journal entries pivot around the figure of the secondary student of EFL and that student teachers feel confident enough as to explicitly assess products, performances, and human behavior along the emotivity and the expectedness parameters. Findings are discussed in relation to the development of the EFL student teachers' professional teaching identity and on the contextual factors that promote it or hinder it.
\end{abstract}


Keywords: evaluative parameters, student teachers, English as a Foreign Language (EFL), secondary education, reflective journal writings, teachers' professional identity.

\section{Resumen}

Este artículo presenta un análisis asistido por ordenador de los principales temas y parámetros de evaluación utilizados por los futuros profesores de inglés como lengua extranjera (ILE) en sus diarios reflexivos. En base al estudio de parámetros de evaluación propuesto por Bednarek, se analizaron 329 entradas de diarios de aula (aproximadamente 90.000 palabras) con la herramienta UAM Corpus Tool. La correlación de tres fuentes de datos (análisis de temas, parámetros de evaluación y palabras clave) permitió mostrar el uso del lenguaje evaluativo que hacen los futuros profesores de inglés y su valoración del proceso de capacitación recibido durante el prácticum en los centros de secundaria. Los resultados muestran que la mayoría de los diarios reflexivos analizados giran en torno a la figura del estudiante de inglés de secundaria y que los futuros profesores de inglés evalúan explícitamente productos, actuaciones y comportamientos humanos en base a los parámetros positivo/negativo y esperado/inesperado. Los resultados se analizan en relación con el desarrollo de la identidad profesional de los futuros docentes de ILE y sobre los factores contextuales que la promueven u obstaculizan.

Palabras clave: parámetros evaluativos, profesores en formación, inglés como lengua extranjera (ILE), educación secundaria, diarios reflexivos, identidad docente.

\section{Introduction}

This paper presents a computer-based discourse analysis of the reflections written by twenty pre-service teachers of English as a Foreign Language (henceforth EFL) during their practicum studies

\section{ELIA 20, 2020, pp. 47-76 DOI: http://dx.doi.org/10.12795/elia.2020.i20.03} 48 
in different secondary schools. Reflective practice is an important feature of many EFL teacher education programs worldwide (Farrell, 1999, 2013, 2018a, 2018b) and a well-known framework for teachers' professional development (Mann \& Walsh, 2017; Newby, Allan, Fenner, Jones, Komorowska \& Soghikyan, 2007). During the practicum studies, student teachers (henceforth STs) are frequently encouraged to produce "small narratives" of different kinds to promote reflection-in-action, that is, to construct pedagogical meaning out of their teaching experiences at school (Vásquez, 2011). Post observation interviews, informal conversations among colleagues and school anecdotes are examples of these "ephemeral narratives emerging in everyday, mundane contexts" (Watson, 2007, p. 371), which are different from "big", retrospective narratives, like teachers' autobiographies or memoires. The potential of these "small" narratives is enormous for language teacher educators. Being able to follow the ongoing process of construction of a nascent professional persona through the analysis of STs' narratives is paramount for university mentors since it allows them to scrutinize the problems trainees may face during the practicum studies and address them pedagogically (Alonso-Belmonte, 2012, 2014).

This paper is particularly focused on the analysis of the typical language choices made by EFL STs in the small narratives produced during their teaching practicum in Secondary Education. This study starts off from the premise that EFL STs make a conscious selection of the language resources used in their narratives to build and project a professional identity they feel comfortable with and that they want to share with other participants in their training process (Alsup, 2006; Beijaard, Meijer \& Verloop, 2004). A review of the literature suggests there is a paucity of research on the linguistic 
or discourse-based aspects of EFL STs' narratives. Albeit some exceptions (Vásquez, 2007; Urzúa \& Vásquez, 2008), most existing studies on ST's voices during the practicum studies are pedagogically oriented and qualitative focused (for a revision, see Lawson, Çakmak, Gündüz \& Busher, 2015). It is alleged here that more quantitative, corpus-oriented studies of STs' language could also provide interesting insights into the construction of STs' nascent professional persona during their teacher training process. To my knowledge, only some scholars like Farr (2011), Farr \& Riordan (2015) and Riordan (2018) and in Spain, Faya-Cerqueiro \& Alcaráz-Mármol (2020), have approached the study of STs' reflective practices using corpus linguistic tools.

Thus, this paper aims to contribute to the dearth of computer-assisted discourse studies on the characteristics of the language used by STs by analyzing the main evaluative parameters used in 329 written reflective journals (aprox. 90,000 words), drawing on Bednarek's parameter-based approach to evaluation (Bednarek, 2006, 2010). Evaluative parameters are the axes along which speakers express their assessments of people, situations, and objects. The written reflective journals analyzed here are a subset of data taken the UAM-ETNA (English Teachers' Narratives) corpus, which is mainly integrated by the recording of mentor-trainees interviews, post-observation meetings and the compilation of written reflective journals produced by STs at the Faculty of Teacher Education at the UAM during their practicum studies at primary and secondary schools.

This paper is organized as follows: section 2 introduces the most relevant literature on evaluative language and evaluative parameters. Section 3 describes the objectives of the study, the

\section{ELIA 20, 2020, pp. 47-76 DOI: http://dx.doi.org/10.12795/elia.2020.i20.03 50}


characteristics of the corpus and the methodology used. Finally, the results are presented and discussed in Sections 4 and 5, respectively.

\section{About Evaluative Language}

Evaluative resources of language allow speakers to convey assessments of people, situations, and objects, and to share and contrast those opinions with other speakers. Research in linguistics has addressed the study of the evaluative meaning using different terms and approaches: attitude (Halliday \& Matthiessen, 2004), evaluation (Hunston \& Thompson, 2000), appraisal (Martin \& White, 2005), and stance (Conrad \& Biber, 2000), among others. In some textually-oriented models of description, evaluation is realized as a structural component present in many text patterns (see Hoey, 2001; Alonso-Belmonte, 2009a and 2009b). For example, in the models proposed by Labov (1972) and later on, by Labov \& Waletzky (1997) for the analysis of narratives, evaluation is the most important structural category as it reveals the real purpose of telling the story to a given audience. For some other scholars, however, evaluation is not confined to a specific part of the text but it is “(...) a dynamical, intersubjective phenomenon that permeates all levels of linguistic description (...)" (Alba-Juez \& Thompson, 2014, p. 13). Indeed, it has often been remarked that evaluative meanings are not easy to quantify because of the multitude and variety of linguistic and pragmatic resources involved in their construction. In this study, this second approach is adopted, and evaluation is understood as a complex, context-determined, pervasive phenomenon in language which reflects the values of a person, group, society, or culture.

This paper revolves around one of the linguistic resources used by speakers to express evaluation: the set of evaluative 
parameters along which STs express their opinions. To explore this issue, Bednarek's parameter-based approach to the study of evaluation in media discourse is particularly enlightening (2006, 2010). For this scholar, writers' assessments are expressed along several evaluative standards or dimensions which are located on a cline of low to high intensity with potential extreme and intermediate stages between them. Thus, on the basis of consulting prior theories of evaluation, appraisal, and stance (Conrad \& Biber, 2000; Hunston \& Thompson, 2000; Martin \& White, 2005), Bednarek proposes a data-driven list of twelve main evaluative parameters which can be identified in discourse with the help of specific rhetorical questions and/or the presence of certain sub-values or keywords associated with one of the two poles of each parameter, as Table 1 shows:

Table 1: Bednarek's evaluative parameters (Bednarek, 2010:35-37)

\begin{tabular}{|l|l|l|}
\hline \multicolumn{1}{|c|}{$\begin{array}{c}\text { Evaluative } \\
\text { parameter }\end{array}$} & \multicolumn{1}{|c|}{ Question } & \multicolumn{1}{|c|}{ Sub-values } \\
\hline \hline $\begin{array}{l}\text { Comprehensi- } \\
\text { bility }\end{array}$ & $\begin{array}{l}\text { How comprehensible or easy, } \\
\text { or how incomprehensible or } \\
\text { difficult, does this appear? }\end{array}$ & $\begin{array}{l}\text { Plain, clear - } \\
\text { mysterious, unclear }\end{array}$ \\
\hline Emotivity & $\begin{array}{l}\text { How positive or how negative } \\
\text { does this appear? }\end{array}$ & Positive / negative \\
\hline Expectedness & $\begin{array}{l}\text { How expected or unexpected } \\
\text { does this appear? }\end{array}$ & $\begin{array}{l}\text { Expected/ } \\
\text { unexpected } \\
\text { contrast / } \\
\text { comparison }\end{array}$ \\
\hline Importance & $\begin{array}{l}\text { How important or how } \\
\text { unimportant does this appear? }\end{array}$ & $\begin{array}{l}\text { Key, major / } \\
\text { minor, slightly }\end{array}$ \\
\hline
\end{tabular}




\begin{tabular}{|c|c|c|}
\hline Genuineness & $\begin{array}{l}\text { How real, true, and authentic, } \\
\text { or how fake, false, and artificial, } \\
\text { does this appear? }\end{array}$ & True / false / real \\
\hline Possibility & $\begin{array}{l}\text { How possible or how } \\
\text { impossible does this appear? }\end{array}$ & $\begin{array}{l}\text { Possible / } \\
\text { not possible }\end{array}$ \\
\hline Necessity & $\begin{array}{l}\text { How necessary or how } \\
\text { unnecessary does this appear? }\end{array}$ & $\begin{array}{l}\text { Necessary/ } \\
\text { not necessary }\end{array}$ \\
\hline Reliability & $\begin{array}{l}\text { How likely or how unlikely } \\
\text { does it appear that this will } \\
\text { happen? }\end{array}$ & Genuine / fake \\
\hline Causality & $\begin{array}{l}\text { What are the reasons and what } \\
\text { are the consequences? }\end{array}$ & $\begin{array}{l}\text { Because... } \\
\text { Consequently }\end{array}$ \\
\hline $\begin{array}{l}\text { Sourcing } \\
\text { (evidentiality) }\end{array}$ & How do we know? & Know, feel \\
\hline $\begin{array}{l}\text { Sourcing } \\
\text { (style) }\end{array}$ & How was it said by sources? & \\
\hline Mental state & $\begin{array}{l}\text { What mental state is attributed } \\
\text { to news actors? }\end{array}$ & $\begin{array}{l}\text { Believe, think, } \\
\text { convinced, assume, } \\
\text { accept, know, fear, } \\
\text { yearn, love, hope, } \\
\text { anxiety, concerns } \\
\text { for, appalled, } \\
\text { furious, troubled, } \\
\text { cheered, happy, } \\
\text { pleasure, enraged, } \\
\text { panic, force, willing } \\
\text { to, intend to, want } \\
\text { to, refuse to }\end{array}$ \\
\hline
\end{tabular}

Bednarek's parameter-based approach to evaluation has been widely used in the study of media discourse. Despite having been “(...) conceptualized as open-ended and organic, with clear potential 
for further redevelopment" (Bednarek \& Caple, 2012; p. 139), the model has been scarcely applied to the analysis of other genres. In the case of narratives, previous small-scale work (Alonso-Belmonte, 2012, 2014; Alajaji, 2015) has shown the applicability of Bednarek's framework to the analysis of reflective texts written by students. However, some interesting questions remain unanswered, related for example, to the use, and frequency and distribution of these evaluative parameters in a bigger sample of teachers' narratives, or to the most typical evaluative language choices made by STs.

\section{The Present Study}

\subsection{Objectives and Research Questions}

This article explores the EFL STs' use of evaluative language in a corpus of journal entries collected during their practicum studies in secondary schools. More specifically, the research questions that guide the analyses here the following:

- What do EFL STs at secondary schools write about in their reflective journals? What pedagogical constructs, events, institutions, and participants etc. do they mention and reflect about?

- What evaluations do they make regarding the previous topics and participants in their written reflections? On what evaluative parameters do they base their assessments? What are the most frequent keywords used for each topic?

- What do all these evaluations tell us about the STs' emergent professional identity as secondary teachers of EFL?

\subsection{Data}

329 reflective journals (aprox. 90,000 words) were analyzed. Table 2 shows the text characteristics: 
Table 2: Sample characteristics (source: UAM Corpus Tool 3.1.14)

\begin{tabular}{|l||l|r|}
\hline \multirow{4}{*}{ Length } & Number of segments & 329.00 \\
\cline { 2 - 3 } & Words in segments & 99619.00 \\
\hline \multirow{4}{*}{ Text complexity } & Av. Word Length & 4.37 \\
\cline { 2 - 3 } & Av. Segment Length & 274.10 \\
\cline { 2 - 3 } & Max. Segment length & 707.00 \\
\hline \multirow{3}{*}{ Lexical Density } & Lexemes per segment & 118.53 \\
\cline { 2 - 3 } & Lexemes \% of text & 43.24 \\
\hline
\end{tabular}

These sample texts were written in English by twenty preservice teachers of EFL who did the Masters' Degree in Teacher training for Compulsory and Upper Secondary Education, Vocational Education and Official Schools of Languages at the Universidad Autónoma de Madrid in four consecutive academic years (2010-2014). In Spain, this masters' degree qualifies its holders to practice a regulated profession and is thus an obligatory requirement for those wishing to undertake secondary, vocational, and language teaching (Spanish Royal Decree 1834/2008 of [ $\left.8^{\text {th }}\right]$ November 2008). STs at the UAM carry out their practicum studies during 25 days in different secondary schools including Official Language Schools in Madrid, at the same time they receive formal education at the UAM Faculty of Teacher Training and Education.

Sample text writers were postgraduate students in their midtwenties. They all gave their prior informed consent to participating 
The Use of Evaluative Language in EFL Teachers' Reflective...

in this project. Table 3 shows the distribution of the sample texts collected by participants and academic year:

Table 3: Distribution of texts by participants and academic year

\begin{tabular}{|c|c|c|r|r|}
\hline Academic year & $\begin{array}{c}\text { No. } \\
\text { student } \\
\text { teachers }\end{array}$ & Gender & $\begin{array}{c}\text { No. } \\
\text { written } \\
\text { journal } \\
\text { entries }\end{array}$ & No. words \\
\hline \hline $2010-2011$ & 4 & Both & 103 & 15789 \\
\hline $2011-2012$ & 2 & Female & 35 & 10255 \\
\hline $2012-2013$ & 7 & Both & 85 & 21120 \\
\hline $2013-2014$ & 7 & Both & 106 & 33016 \\
\hline TOTAL & 20 & & 329 & 90180 \\
\hline
\end{tabular}

\subsection{Method and Procedure}

Data was collected as follows: for each week of teacher training at secondary schools, STs were asked to write up to three "reflective moments" (average length of 300 words each) in English about different pedagogical situations that arose during the week. These entries could be triggered by very recent or still unfolding pedagogical events, conversations, thoughts or feelings of any kind, which were seen as opportunities to reflect, respond, and keep track of field experience, but also to perform other social functions such as highlight and resolve tensions, justify or explain their actions (or those of others) and construct a particular professional identity as teachers (Bailey, 1990; Bailey, Curtis \& Nunan, 2001; Golombek, 1998; Gray, 1998). STs were also asked to label their entries

\section{ELIA 20, 2020, pp. 47-76 DOI: http://dx.doi.org/10.12795/elia.2020.i20.03 56}


according to the topic chosen: students, school, personal, university and other. At the end of every week, journal entries were e-mailed to the STs' university mentors, who could ask to review them with the candidate at any time. These journals were a course requirement, but they were not graded, to ensure truthful reflections. Besides, they were complemented by post-observation meetings and other informal conversations between the students and the university mentor.

Once the 329 diary entries had been gathered, data was saved and given a numeric code to identify the author and his/her diary entry (e.g. S_RJ9a). Besides, each text was classified according to other variables, such as the type of school where STs carried out their practicum (public, private, subsidized or an Official Language School), and the main topics dealt with in each entry. Then, texts were annotated and analyzed by using the UAM Corpus Tool (O' Donnell, 2008), version 3.1.14. This program was used to generate descriptive statistics and to signal frequent wording and keywords, that is, words and word phrases whose frequency in the texts are statistically significant (Bondi \& Scott, 2010). Keyness propensity (=P) was also measured. The UAM Corpus Tool was also used to classify each one of the 8675 units of evaluative language -mainly sentences- identified according to their level of explicitness, the evaluative parameter used (Bednarek, 2006) and to its degree of intensity (high/medium/low). For example, the sentence "the outcome was terrible" (AMT_RJ12) was analyzed as an explicit evaluative act (terrible), based on the parameter of expectedness and with a high degree of intensity.

Finally, to verify the stability of the coding, 150 randomly chosen texts were re-coded independently by two trained raters. Their inter-rater reliability was $70 \%$. After comparison of the results, some of the codes for these sample texts were revised to reduce discrepancy between raters. 
The Use of Evaluative Language in EFL Teachers' Reflective...

Then the coding of the entire corpus was checked for any disparity between the original and revised coding. The resulting coding of the corpus yielded an overall inter-reliability rate of 0.90 (Cohen's Kappa statistics) which is considered almost perfect.

\section{Results}

For presentation purposes, findings are reported under the following subsections: main themes, main evaluative parameters and main evaluative choices and keywords across topics.

\subsection{Main Emergent Themes}

Results show that most reflective journals are mainly concerned with five topic categories: student-based topics, personal-based topics, school-based topics, university-based topics and finally, other issues. Table 4 shows the list in descending order:

Table 4: Emergent themes

\begin{tabular}{|l|r|r|}
\hline \multicolumn{1}{|c|}{ Categories } & No. texts & No. evaluative acts \\
\hline \hline Student-based topics & 125 & 3195 \\
\hline School-based topics & 111 & 2453 \\
\hline Personal-based topics & 78 & 2608 \\
\hline University-based topics & 24 & 312 \\
\hline Other & 11 & 107 \\
\hline TOTAL & 349 & 8675 \\
\hline
\end{tabular}

Data show that STs depart from abstract and theoretical reflections and follow a bottom-up reasoning process by discussing on issues which directly emerge out of their teaching experiences at school. As a matter of fact, most diary entries pivot around the figure of the secondary student of EFL, which is presented as the STs' main 
source of motivation and their main reason to undertake professional practice as teachers:

(1) I can see they are unmotivated (...) they do not see any benefit from studying (...) topics chosen are old fashioned and boring. (...) How can they think of learning as an enjoyable activity? (DB_RJ1)

(2) They are lovely and I have to confess I do not want to leave the school (AMT_RJ10)

More specifically, 35,8\% of the reflective journals analyzed are focused on the description and assessment of the secondary students' characteristics, their capacities, and their level of performance at school:

(3) They are eager to participate in the activities (S_CS_RJ1)

(4) 1st Bachillerato is a disruptive class (S_VF_RJ5b)

(5) Students from the bilingual section are more motivated to participate in class, probably because they feel more secure about their knowledge of English (MGRF_RJ1a)

$31,8 \%$ of the journals analyzed deal with school-based topics. In these texts STs specially reflect on the productivity and feasibility of certain activities, resources, techniques, and evaluation practices. Table 5 shows the list of school-based topics in descending order:

Table 5: School-based topics: subcategories

\begin{tabular}{|l|r|r|}
\hline \multicolumn{1}{|c|}{ Subcategories } & No. $=2453$ & \multicolumn{1}{c|}{$\%$} \\
\hline \hline EFL teaching techniques and resources & 1207 & 49.2 \\
\hline Textbooks \& materials & 105 & 4.2 \\
\hline $\begin{array}{l}\text { Participants (e.g. school mentor; university } \\
\text { mentor, etc.) }\end{array}$ & 100 & 4.0 \\
\hline Other (e.g. Attention to diversity, etc.) & 38 & 1.5 \\
\hline
\end{tabular}


As table 5 shows, STs do not devote much time to reflect on their professional relationship with other participants in their practicum studies (i.e. the school mentor, the university mentor and/or other colleagues at school). The case of the evaluative acts on school mentors is worth a comment. Although relatively small in amount, the evaluative instances analyzed show how some STs report feeling discomfort with their school mentors, who may not devote enough time or attention to their training process. Examples 6,7 and 8 illustrate this point:

(6) My mentor continues to be as friendly as usual, but she has large piles of notebooks and exams to correct so she does not have the time to teach me her method (DB_RJ1)

(7) My mentor is extremely busy and it would be very complicated to prepare a class together before hand (Sa_RJ9a)

(8) She is really busy and I do not want to disturb her (MER_RJ1a)

STs also speak about themselves, about their personal expectations and feelings concerning their secondary students and the school where they are placed in. $22,34 \%$ of the diary entries analyzed specifically tackle personal-based topics. Results show that writers are particularly concerned with their own level of performance as schoolteachers, trying to reach high standards:

(9) When it comes to $4^{\text {th }}$ C I feel completely helpless (EM_RJ4b)

(10) I could have included more interactive activities in the teaching unit (VF_RJ11b)

Findings also show that there are just a few mentions in the corpus to the university institution STs are doing their master's degree. These references are mainly limited to the description of the teacher training activities suggested by the university mentors and the relationship between these activities and the practicum studies. 
From the analysis journal diaries one can derive that most STs experience theory and practice as fragmented:

(11)I am not really enjoying it (the practicum) because my mind is constantly shifting from the master to the practicum and I cannot focus on a single thing (AR_RJ9)

(12) Why am I not being taught this kind of practical things in the Master’s program? (J_RJ10a)

\subsection{Main Evaluative Parameters across Topics}

Results show that STs tend to place their views about the abovementioned topics along two main evaluative clines: the one of expectedness and the one of emotivity (positive/negative).

(13) I did not expect one of the activities would foster so much oral interaction (Em_RJ9b)

(14) Most students are very polite and have a good behavior (S_J_RJ3)

As the examples show, writers tend to frame their school experiences as good or bad and/or as fitting (or not) with their expectations. Besides, it is frequent to find the evaluative parameters of emotivity and expectedness overlapping in a single sentence, as an example of what Bednarek calls evaluative interplay (2008). Instances nos. 15 and 16 illustrate cases of evaluative conflation, the most frequent one in the corpus, where the same terms (daydreaming, chatting) signal the presence of two different parameters (emotivity and expectedness) in one evaluative act:

(15) Some students were daydreaming (EM_RJ4b)

(16)They were chatting all the time (AMT_RJ3) 
The evaluation of the secondary students' behavior as both to be expected and negative enhances a pessimistic outlook on the classroom environments at school. On the contrary, to assess something as both unexpected and positive is used by STs to highlight their enthusiasm with specific teaching experiences, as the cases in point:

(17)The result was amazing. The session had nothing to do with the previous one (AMT_RJ12)

STs' reflective journals are fraught with comparisons among students, groups, teachers, materials and teaching practices:

(18) In my 1st ESO class the English teacher is also the Jefa de Estudios and she has a more authoritarian approach. I think students have a greater fear/respect for this teacher (SMW_RJ1)

(19) Being able to share what I have experimented during my classroom sessions with him (the school mentor) has been of great help. I can see now that we both have the same problems: students misbehave and are bored. The only difference is that he is more experienced than me and I have not got so many teaching strategies to manage the class as he has (MA_RJ11b)

Examples 17, 18 and 19 illustrate the prevalence of the comparison, contrast, and negation sub-values in the corpus. These cases also unveil the STs' tendency to write down anything which deviates from their high expectations regarding the schools, their students or their own performance as a teacher. Table 6 shows the details: 
Table 6: Frequent wording of the expectedness parameter

\begin{tabular}{|l|c|r|}
\hline \multicolumn{1}{|c|}{ Expectedness parameter } & No. $=1,854$ & \multicolumn{1}{c|}{$\%$} \\
\hline \hline Comparison (not, no, hardly, only) & 926 & 49.9 \\
\hline Contrast (but, however) & 721 & 38.8 \\
\hline Unexpected (astonishing, surprising) & 104 & 5.6 \\
\hline Expected (familiar, inevitably) & 103 & 5.5 \\
\hline
\end{tabular}

In general, most evaluations are explicit. Only $36.8 \%$ of the evaluative acts analyzed are implicit assessments, as the cases in point:

(20) He follows the textbook page by page. (ELM_RJ5a)

(21) She has been teaching for 25 years. (AM_RJ10)

The evaluative and expectedness parameters are followed at great distance by the ones of possibility, reliability, and necessity. In other words, STs assess what is possible, probable, and needed in the EFL classroom to demand the necessary instructional adjustments at school:

(22) If a teacher creates good atmosphere, students will feel comfortable and feel free to express themselves and ask questions (CS_RJ8)

(23) Students need help with their oral exams (L_RJ13)

(24) They really need to improve their oral skills (Sa_RJ3a)

Examples 23 and 24 are inclined to the negative pole of the necessity axis as the STs' demand to do something to help their students.

Table 7 shows the list of evaluative parameters used in the corpus, with the number of occurrences for each evaluative parameter and their frequency in the corpus. The table also 
The Use of Evaluative Language in EFL Teachers' Reflective...

offers information about the most frequent highlighted poles and sub-values associated to each parameter.

Table 7: Bednarek's evaluative parameters and their linguistic realization in EFL STS' narratives

\begin{tabular}{|c|c|c|c|c|}
\hline $\begin{array}{l}\text { Evaluative } \\
\text { parameter }\end{array}$ & $\begin{array}{l}\text { No: } \\
8,688\end{array}$ & $\%$ & $\begin{array}{l}\text { Intensity } \\
\text { pole }\end{array}$ & Sub-values \\
\hline Emotivity & 3623 & 41.70 & $\begin{array}{l}\text { Positive } \\
(56.9 \%)\end{array}$ & $\begin{array}{l}\text { Problem(s); } \\
\text { interesting, good, } \\
\text { better best, } \\
\text { positive, mistakes, } \\
\text { happy, nervous, } \\
\text { great, nice, correct, } \\
\text { enjoyed, bored, } \\
\text { boring. }\end{array}$ \\
\hline Expectedness & 1854 & 21.34 & $\begin{array}{c}\text { Comparison } \\
(49.94 \%)\end{array}$ & $\begin{array}{l}\text { But, not, however, } \\
\text { only, surprised, } \\
\text { shocking, usual }\end{array}$ \\
\hline Possibility & 594 & 6.84 & $\begin{array}{l}\text { Possible } \\
(81.4 \%)\end{array}$ & Can, could, possibly \\
\hline Reliability & 569 & 6.55 & $\begin{array}{c}\text { High } \\
(68.71 \%)\end{array}$ & Will \\
\hline Necessity & 506 & 5.82 & $\begin{array}{c}\text { Necessary } \\
(95.6 \%)\end{array}$ & Had, have to, need, \\
\hline Causality & 434 & 5.00 & & Because \\
\hline Comprehensibility & 421 & 4.85 & $\begin{array}{l}\text { Difficult } \\
(64.6 \%)\end{array}$ & $\begin{array}{l}\text { Difficult, easy, } \\
\text { understand, }\end{array}$ \\
\hline
\end{tabular}

ELIA 20, 2020, pp. 47-76 DOI: http://dx.doi.org/10.12795/elia.2020.i20.03 64 


\begin{tabular}{|l|l|l|l|l|}
\hline Importance & 408 & 4.70 & $\begin{array}{c}\text { Important } \\
(99.5 \%)\end{array}$ & $\begin{array}{l}\text { Mentor, tutor, } \\
\text { important, advisor, } \\
\text { teacher }\end{array}$ \\
\hline Genuineness & 269 & 3.10 & $\begin{array}{c}\text { Authentic } \\
(80.2 \%)\end{array}$ & $\begin{array}{l}\text { Real, authentic, } \\
\text { original, true }\end{array}$ \\
\hline
\end{tabular}

Table 7 summarizes some interesting results which are worth commenting on. To start with, it shows that overall, STs' evaluations are slightly inclined to the positive pole of each evaluative axis. Examples (25) and (26) illustrate this pattern of optimistic, in-depth introspective reflections, very frequent in the corpus:

(25) Being a teacher-in-training makes me value many aspects that I didn't give much importance to when I was a student. One of these things is the student's behavior in the class. (AR_RJ2b)

(26) This practicum has given me the opportunity to experience school life again. (MGRF_RJ8)

Secondly, as the previous examples show, the sub-values that go along the different evaluative parameters are genre-constrained and highlight the keyness of the didactic terms in the corpus: students, behavior, practicum, textbooks, authentic, etc. The following section will present the evaluative choices and keyness across topics.

\subsection{Evaluative Choices and Keyness across Topics}

When reflecting on student-based topics, STs place their assessments along three main clines: the emotivity, the expectedness and the 
necessity parameters. Findings show that the first two parameters are mostly used in the corpus when evaluating the secondary students' level of English, their psychological disposition to learn and their behavior in class.

(27) This week the students had an English test and most of them failed it! (TG_RJ3)

(28) Students who follow Alive textbook have a lower command of English (AMT_RJ6)

(29) These students seem to be more motivated than those of the other group (AR_RJ10b)

(30) It is much more annoying when students are demotivated and apathetic, even if they are quiet (CLP_RJ2)

(31) Most of them were not paying attention; they were chatting and laughing (ELM_RJ13)

The propensity to discuss and assess students' level of English and their capacity of understanding is highlighted by the presence of these keywords in the corpus: Understood $(\mathrm{P}=100)$, low $(\mathrm{P}=75.86)$ and advanced $(\mathrm{P}=54.54)$. As for the secondary students' behavior, the propensity analysis shows they are described to be participative $(\mathrm{P}=59,50)$ and maybe a consequence of this, disruptive $(\mathrm{P}=55)$. As a matter of fact, one of STs' main concerns is how to manage their students' behavior:

(32) They were talking to each other in Spanish as if I was invisible (EM_RJ6a)

(33) They were becoming noisy and did not follow me at all (MA_RJ5)

(34) It became impossible to manage the situation (MA_RJ6b)

Table 8 shows the most frequent keywords in the corpus when the journal entries revolve around secondary students' behavior and discipline: 
Table 8: Key terms related to EFL students' behavior and discipline

\begin{tabular}{|l|c|}
\hline \multicolumn{1}{|c|}{ Key terms } & Propensity $(=\mathrm{P})$ \\
\hline \hline Misbehaving & $\mathrm{P}=35.00$ \\
Behaved & $\mathrm{P}=27.64$ \\
Quiet & $\mathrm{P}=20.43$ \\
Properly & $\mathrm{P}=16.54$ \\
Talking & $\mathrm{P}=11.91$ \\
\hline
\end{tabular}

When reflecting about school-based topics, STs tend to assess the functionality and productivity of specific activities, techniques, and evaluation practices, mainly along the clines of emotivity and expectedness. Most STs' assessments of classroom activities are slightly inclined to the negative pole of these clines, as the examples show:

(35) I found the exercise useless, boring and too repetitive (ELM_RJ10b)

(36) The rest of the sessions were not so remarkable (JC_RJ3)

This interpretation is in line with the propensity and the high degree of intensity of the terms disaster $(\mathrm{P}=40)$ or boring $(\mathrm{P}=25)$ in the corpus. Table 9 shows the most frequent keywords used by STs when speaking about the classroom activities:

Table 9: Key terms related to classroom activities

\begin{tabular}{|c|c|}
\hline Key terms & Propensity $(=\mathrm{P})$ \\
\hline \hline Disaster & $\mathrm{P}=40.00$ \\
Digital & $\mathrm{P}=25.00$ \\
Boring & $\mathrm{P}=25.00$ \\
Original & $\mathrm{P}=19.00$ \\
Interactive & $\mathrm{P}=15.00$ \\
\hline
\end{tabular}


As for EFL textbooks and materials, writers' evaluations highlight their utility, their attractiveness and also their deficiencies, as the cases in point:

(37)Textbooks reinforce gender stereotypes too. (ELM_RJ10b)

(38) Most textbook-based exercises are too easy and students get bored after doing one or two of them. (ELM_RJ4a)

However, in general terms it can be said that assessments on didactic materials are positive. This interpretation is supported by the presence in the corpus of the key terms useful and appealing, among others. Table 10 shows the details:

Table 10: Key terms related to textbooks \& materials

\begin{tabular}{|l|c|}
\hline \multicolumn{1}{|c|}{ Key terms } & Propensity $(=\mathrm{P})$ \\
\hline \hline Useful & $\mathrm{P}=25.00$ \\
Appealing & $\mathrm{P}=17.00$ \\
Simple & $\mathrm{P}=16.00$ \\
Lack & $\mathrm{P}=15.23$ \\
\hline
\end{tabular}

Finally, STs also write about themselves in their diaries. They express their own personal expectations and feelings with intensity, sometimes, related to the success or failure of specific teaching practices; some other times, regarding their secondary students' reactions or behavior in the class. In all cases, the expectedness parameter is the most used evaluative cline in the corpus, in combination with different kinds of mental and emotional verbs (know, realize, understand, feel...):

(39)It is a bit disappointing to realize that what you prepared does not work as planned (J_RJ10a)

(40) At the beginning, students did not understand what they had to do. It was a total disaster. I was a bit disappointed. The 
outcome was terrible (...). The second session was better. (...) the result was awesome (S-AMT_RJ12)

Most writers' evaluations reflect the high standards they set to themselves regarding their own teaching performance:

(41) I knew teaching teenagers was not going to be an easy task (AR_RJ2a)

(42) I have learned a lot of things from my students I could have never imagined (AM_RJ13)

STs are not particularly emotional writers, but they tend to express feelings of insecurity, stress, and discomfort in their diaries, especially at the beginning of their practicum studies:

(43) I am running out of time and of ideas, and just getting more stressed every single day (AR_RJ9)

(44) I am still tense, but I am improving (AM_RJ6)

(45) I feel as a puppet. I do everything my mentor asks me to do but I cannot make my own decisions. I know this is normal, but my feelings remain still (J_RJ/b)

This is in line with the propensity of terms like nervous or stressed. Table 11 shows some of the most common keywords present in the corpus:

Table 11: Key terms related to personal-based topics

\begin{tabular}{|l|c|}
\hline \multicolumn{1}{|c|}{ Key terms } & Propensity $(=\mathrm{P})$ \\
\hline \hline Nervous & $\mathrm{P}=124.75$ \\
Stressed & $\mathrm{P}=73.00$ \\
Comfortable & $\mathrm{P}=33.47$ \\
Pleased & $\mathrm{P}=33.47$ \\
Happy & $\mathrm{P}=23.33$ \\
\hline
\end{tabular}


Progressively, however, STs gain confidence in themselves during their training process and end up their practicum studies with a positive note:

(46)I am no longer nervous. I think each day is better for me (AM_RJ9)

(47)I feel more and more comfortable (J_RJ11b)

(48) I have really liked my training, my mentor and my lovely students (AMT_RJ10)

\section{Discussion}

The correlation of three sources of data - topics, evaluative parameters and keywords - has allowed to uncover the most typical evaluative language choices made by EFL STs in their reflective journal writings and their overall evaluation of their training process during their practicum studies. Results show that STs mainly devote their journals to write about their secondary students and to assess the different aspects that affect their learning process along the emotivity and the expectedness parameters. These clines are ubiquitous in the corpus, also when STs assess the functionality and productivity of specific activities, techniques, and evaluation practices or when they write about themselves, their worries and concerns. However, while most STs' evaluations of the existing didactic materials and textbooks are fairly positive (useful, appealing), the outcome of their own class activities usually falls below their expectations (disaster), which is a clear sign of the high standards set by STs themselves regarding their own teaching performance. Overall, STs' reflective journals are mainly the narrative expression of the emotional roller coaster of teaching, fraught with different personal expectations (nervous), frustrations (stressed) and feelings (happy). In the end, however, STs tend to

\section{ELIA 20, 2020, pp. 47-76 DOI: http://dx.doi.org/10.12795/elia.2020.i20.03} 70 
portray themselves as motivated, satisfied trainees who generally evaluate their practicum studies as a success.

On the basis of these findings, I believe it is safe to claim that the average UAM student teacher's public self is well balanced and hints at stable degrees of self-worth and self-esteem, basic characteristics of a solid professional teaching identity (Rodgers and Scott, 2008). Except for the constant misbehavior of some students, which is the only source of tension in the class (nervous, stressed), STs' assessments about their teaching experience at school echo confidence and optimism along the corpus. Another sign of the student teachers' high self-worth is the constant presence of the expectedness parameter underlying their evaluations; UAM STs do not judge themselves as lacking in capacity, but show determination to reach the high standards of achievement set by STs themselves.

It remains to be explored whether the results obtained in this study can be generalized or not, particularly when other contextual variables come into play during the practicum studies. External factors like the school type, the relationship between STs and their school and/or their university mentors, the trainees' own personality and age, etc. may enhance or undermine STs' motivation and in turn, their evaluative language choices. To address this issue, the UAM ETNA corpus should be further expanded to be able to linguistically describe the discourse construction of the EFL STs' professional self in their journal writings, a genre far from being portrayed.

\section{Conclusion}

Results presented in this paper have yielded interesting insights into the way evaluations function in STs' reflective journals. I believe 
studies like this one offer potential to provide valuable insights for EFL teacher trainers working in foreign language teacher education programs. For example, on the basis of the results presented, some prevention strategies could be developed by teacher trainers to avoid problems like the disconnection between school and university reported by STs or the rather distant role attributed in the corpus to both school and university mentors.

\section{Acknowledgments}

This work was supported by the Spanish Ministry of Science and Competitiveness (Research Project FFI2016-77540-P).

\section{References}

Alba-Juez, L. \& Thompson, G. (2014). Evaluation in Context. Amsterdam and Philadelphia:John Benjamins. https://doi.org/10.1075/pbns.242

Alajaji, N. (2015). How medical students express their attitudes towards their reflective experience in teaching hospitals: A corpus-based approach to the analysis of evaluation in reflective reports. Unpublished doctoral thesis. The University of Birmingham.

Alsup, J. (2006). Teacher Identity Discourses: Negotiating Personal and Professional Spaces. Mahwah, NJ: Lawrence Erlbaum Associates. https://doi.org/10.4324/9781410617286

Alonso-Belmonte, I. (2009a). Towards a genre-based characterization of the problem solution textual pattern in English newspaper editorials and op-eds. Text \& Talk, An Interdisciplinary Journal of Language, Discourse \& Communication Studies, 29(4), 393-414. https://doi.org/10.1515/TEXT.2009.021

Alonso-Belmonte, I. (2009b). Positioning the reader: a study on the use of interactive textual patterns in English written newspaper editorials and articles of opinion. English Text Construction, 2(1), 48-69. https://doi.org/10.1075/etc.2.1.03alo 
Alonso-Belmonte, I. (2012). I feel as if I were a real teacher: an analysis of EFL student teachers' evaluative discourse through Appraisal theory. In M. Hernández \& M. J. González (Eds.), Revista Canaria de Estudios Ingleses. Evaluative Uses of Language: The Appraisal Framework (pp. 13-27). Universidad de La Laguna.

Alonso-Belmonte, I. (2014). Genre and Professional Identity: An Exploratory Study on the Female Student Teachers' Evaluation of Experience in EFL. In Sánchez Macarro, A. \& Cabrejas Peñuelas, A.B. (Eds.), New Insights into Gendered Discursive Practices: Language, Gender and Identity Construction (pp. 241-262). English in the World Series. Valencia: Servicio de Publicaciones de la Universidad de Valencia.

Bailey, K. M. (1990). The use of diary studies in teacher education programs. In J. C. Richards \& D. Nunan (Eds.), Second language teacher education, (pp. 215-226). New York: Cambridge University Press.

Bailey, K. M., Curtis, A., \& Nunan, D. (2001). Pursuing professional development: The self as source. Boston, MA: Heinle \& Heinle.

Bednarek, M. (2006). Evaluation in media discourse: Analysis of a newspaper corpus. London: Continuum.

Bednarek, M. (2008). An increasingly ‘familiar tragedy': evaluative collocation and conflation. Functions of Language, 15(1), 7-34. https://doi.org/10.1075/fol.15.1.03bed

Bednarek, M. (2010). Evaluation in the news - A methodological framework for analyzing evaluative language in journalism. Australian Journal of Communication, 372), 15-50.

Bednarek, M. \& Caple, H. (2012). News Discourse. London/New York: Continuum.

Beijaard, D., Meijer, P. C., \& Verloop, N. (2004). "Reconsidering research on teachers' professional identity”. Teaching and Teacher Education, 20 (2): 107-128. https://doi.org/10.1016/j.tate.2003.07.001

Bondi, M. \& Scott, M. (Eds.). (2010). Keyness in Texts. Amsterdam / Philadelphia: John Benjamins Publishing Company. https://doi.org/10.1075/scl.41 
The Use of Evaluative Language in EFL Teachers' Reflective...

Conrad, S. \& Biber, D. (2000). Adverbial Marking of Stance in Speech and Writing. In S. Hunston \& G. Thompson (Eds.), Evaluation in Text: Authorial Stance and the Construction of Discourse (pp. 56-73). Oxford: Oxford University Press.

Farr, F. (2011). The Discourse of Teaching Practice Feedback. An investigation of spoken and written modes., New York: Routledge. https://doi.org/10.4324/9780203846742

Farr, F. \& Riordan, E. (2015). Tracing the reflective practices of student teachers in online modes. ReCALL, 27(1), 104-123. https://doi.org/10.1017/S0958344014000299

Farrell, T. S. C. (1999). Reflective practice in an EFL development group. System, 27, 157-172. https://doi.org/10.1016/S0346-251X(99)00014-7

Farrell, T. S. C. (2013). Reflective Writing for Language Teachers. Sheffield, England: Equinox Publishing Lt.

Farrell, T. S. C. (2018a). Research on Reflective Practice in TESOL. New York: Routledge. https://doi.org/10.4324/9781315206332

Farrell, T. S. C. (2018b). Reflective Language Teaching: Practical Applications for TESOL Teachers. 2nd ed. London, UK: Bloomsbury.

Faya-Cerqueiro, F. \& Alcaraz-Mármol, G. (2020). The Toledo Teacher Trainees corpus (TTT): Bridging the gap between students' narratives and corpus linguistics. Research in Corpus Linguistics, 8(1), 164-177. https://doi.org/10.32714/ricl.08.01.10

Golombek, P. R. (1998). A study of language teachers' personal practical knowledge. TESOL Quarterly, 32(3): 447-64. https://doi.org/10.2307/3588117

Gray, J. (1998). The language learner as teacher: the use of interactive diaries in teacher training. ELT Journal, 52(1), 29-37. https://doi.org/10.1093/elt/52.1.29

Halliday, M. \& Matthiessen, C. (2004). An Introduction to Functional Grammar. London: Hodder Arnold.

Hoey, M. (2001). Textual interaction: an introduction to written discourse analysis. London and New York: Routledge. 
Hunston, S. \& Thompson, G. (Eds.) (2000). Evaluation in Text Authorial Stance and the Construction of Discourse. Oxford: Oxford University Press.

Labov, W. (1972). Language in the Inner City. Philadelphia: University of Pennsylvania Press.

Labov, W. \& Waletzky, J. (1997) [1967]. Narrative Analysis: Oral Version of Personal Experience. Journal of Narrative and Life History, 71-4), 338. https://doi.org/10.1075/jnlh.7.02nar

Lawson, T., Çakmak, M., Gündüz, M. \& Busher, H. (2015). Research on teaching practicum - a systematic review. European Journal of Teacher Education, 38(3), 392-407. https://doi.org/10.1080/02619768.2014.994060

Martin, J. R. \& White, P. R. R. (2005). The Language of Evaluation: Appraisal in English. London/New York: Palgrave/Macmillan

Mann, S. \& Walsh, S. (2017). Reflective Practice in English Language Teaching Research-Based Principles and Practices. Taylor and Francis. https://doi.org/10.4324/9781315733395

Newby, D., Allan, R., Fenner, A.B., Jones, B., Komorowska, H., \& Soghikyan, K. (2007). The European Portfolio for Student Teachers of Languages (EPOSTL). Strasbourg: The Council of Europe.

O’Donnell, M. (2008). The UAM CorpusTool: Software for corpus annotation and exploration. In C. M. Bretones Callejas et al. (Eds.), Applied Linguistics Now: Understanding Language and Mind (pp. 1433-1447). Almería: Universidad de Almería.

Riordan, E. (2018). TESOL Student Teacher Discourse. A Corpus-Based Analysis of Online and Face-to-Face Interactions. New York: Routledge. https://doi.org/10.4324/9781315682297

Rodgers, C. R. \& Scott, K. H. (2008). The development of the personal self and professional identity in learning to teach. In M. Cochran-Smith, S. Feiman Nemser, D. J. McIntyre, \& K. E. Demers (Eds.), Handbook of Research on Teacher Education (pp. 732-755). New York: Routledge, Taylor \& Francis Group/Association of Teacher Educators.

Urzúa, A. \& Vásquez, C. (2008). Reflection and professional identity in teachers' future-oriented discourse. Teaching and Teacher Education, 24, 19351946. https://doi.org/10.1016/j.tate.2008.04.008 
The Use of Evaluative Language in EFL Teachers' Reflective...

Vásquez, C. (2007). Moral stance in the workplace narratives of novices. Discourse studies, 95), 653-675. https://doi.org/10.1177/1461445607081270

Vásquez, C. (2011). TESOL, teacher identity, and the need for "small story" research. TESOL Quarterly, 45(3), 535-545. https://doi.org/10.5054/tq.2011.256800

Watson, C. (2007). Small Stories, Positioning Analysis, and the Doing of Professional Identities in Learning to Teach. Narrative Inquiry, 172): 371-389. https://doi.org/10.1075/ni.17.2.11wat

First version received: June, 2020 Final version accepted: October, 2020 